\title{
BMJ Global Health Leaving no one behind in prison: improving the health of people in prison as a key contributor to meeting the Sustainable Development Goals 2030
}

\author{
Nasrul Ismail (D) , ${ }^{1,2}$ Audrey Lazaris (D) , Éamonn O'Moore (D) , ${ }^{4}$ \\ Emma Plugge (D) , ${ }^{4,5}$ Sunita Stürup-Toft (D) ${ }^{6}$
}

To cite: Ismail N, Lazaris $A$, O'Moore É, et al. Leaving no one behind in prison: improving the health of people in prison as a key contributor to meeting the Sustainable Development Goals 2030. BMJ Global Health 2021;6:e04252. doi:10.1136/ bmjgh-2020-004252

Handling editor Stephanie M Topp

Received 19 0ctober 2020 Revised 3 March 2021 Accepted 7 March 2021
Check for updates

(c) Author(s) (or their employer(s)) 2021. Re-use permitted under CC BY. Published by BMJ.

For numbered affiliations see end of article.

Correspondence to

Nasrul Ismail;

Nasrul.Ismail@uwe.ac.uk

\section{ABSTRACT}

Worldwide, approximately 11 million people are currently being held in prison, a number that has steadily grown since the turn of the 21 st century. The prison population is more likely to suffer from physical and mental ailments both during and prior to their imprisonment due to poverty, social exclusion and chaotic lifestyles. Recognition of people in prison is noticeably absent from the Sustainable Development Goals (SDGs), despite the goals' ethos of 'leaving no one behind'.

We present the first analysis of how improving the health of people in prison can contribute to achieving 15 SDGs. Relevant indicators are proposed to fulfil these goals while meeting the existing international prison health standards. We also assess the political, economic and social challenges, alongside the unparalleled COVID-19 pandemic that can thwart the realisation of the SDGs. To reach the 'furthest behind first', prison health must be at the forefront of the SDGs.

\section{INTRODUCTION}

The Sustainable Development Goals (SDGs) $2030^{1}$ seek, among other aims, to catalyse transformations in global health. With 17 goals, 169 targets and 230 indicators that UN member states are responsible to deliver, measure and monitor, the SDGs are calibrated to be comprehensive and ambitious, pledging to 'leave no one behind' and requiring governments to reach 'the furthest behind first'. 1

Imprisoned people are undoubtedly the 'left behind'. Numbering over 11 million globally at any one time, these people come from the most deprived sections of society and have extensive health needs which can be exacerbated by poor prison conditions. ${ }^{2}$ Compared with the general population, people in prison are more likely to suffer from physical and mental illnesses, ${ }^{3}{ }^{4}$ due in large part to the political, economic, environmental, social and lifestyle

\section{Summary box}

- The 11 million people in prison globally comprise the 'left behind', given their extensive health needs underpinned by adverse political, economic, environmental, social and lifestyle factors prior to imprisonment.

- As the Sustainable Development Goals (SDGs) pledge to leave no one behind, improving the health of imprisoned people can contribute to achieving 15 SDGs-from ending poverty in all forms to enabling peace, justice and strong institutions-while enabling states to simultaneously meet the existing international prison health standards.

- There are many opportunities for, and threats to, prison health in realising the attainment of SDGs that are institution specific (eg, overcrowding), as well as political (eg, populism) and economic conditions; the global COVID-19 pandemic has further magnified obstacles around the timely attainment of many goals.

- This analysis informs the development of standards and indicators in prisons that can subsequently be applied to wider areas of the criminal justice system and to different health services.

factors prior to their imprisonment. The association between poverty and social exclusion and the negative impact of these factors on health is indisputable, ${ }^{5}$ and growing evidence demonstrates that health interventions on individuals in prison has positive impacts for their family and wider social network. ${ }^{6}$

Emerging evidence on the COVID-19 pandemic demonstrates that it is disproportionately affecting certain groups and widening health inequalities. ${ }^{7}$ It is therefore particularly important now, when the 'left behind' are at greater risk of becoming further behind, that we recognise that more can be done to improve the health and wellbeing of this vulnerable population. 
Substantial progress has been made in translating the SDGs to areas such as mental health, ${ }^{8}$ maternal and adolescent health, ${ }^{9}$ and sexual and reproductive health. ${ }^{10}$ However, neither the Millennium Development Goals (MDGs), which preceded the SDGs, nor the SDGs themselves have made specific reference to the health of people in prison. This gap in international health strategies overlooks the potential contribution of prison health to the SDGs, with the result that imprisoned people become even further marginalised.

Therefore, this paper articulates the potential contributions of improved prison health to the attainment of the SDGs at a time when the global COVID-19 pandemic is threatening the timely attainment of many goals. ${ }^{11}$ In line with the WHO's definition of 'prisons', we use the term to refer to institutions that hold people sentenced, on trial or awaiting sentence, to a period of imprisonment by the courts for offences against the law, as well as other forms of compulsory detention, such as police cells, immigration removal centres and secure mental health institutions, acknowledging that the term can vary from one country to another. ${ }^{12}$ We first propose a conceptual framework for a prison health agenda in 2030 that aligns with the SDGs. Second, we demonstrate how such a framework is compatible with existing international concordats. Although they are not legally binding, their political weight serves as a continual reminder to the government that it should protect individuals' entitlement to health and healthy living provisions during imprisonment, which would demonstrate the government's commitment to upholding the human right to healthcare. Finally, we carefully consider both the opportunities for and threats to prison health as these relate to the aspirations embedded in the SDGs to promote and sustain a real-world impact on policy and practice. This paper provides a first step towards developing a standard that can subsequently be applied to wider areas of the criminal justice system and different health services to enable monitoring across time and geographical regions.

\section{INTERSECTIONS OF THE PRISON HEALTH AGENDA AND THE SDGS}

The majority of SDGs are interrelated and mutually reinforcing (figure 1 and table 1 ). To ensure a holistic assessment, we adopt a broad lens on prison health, namely the WHO's definition of health as 'a state of complete physical, mental and social well-being and not merely the absence of disease and infirmity'. ${ }^{13}$ This characterisation requires us to consider the social determinants of health, which include poverty and education.

Adopting this broad lens on prison health reinforces the principle that good prison health is good public health. As prisoners often come from the most deprived sections of society and experience the greatest health needs, ${ }^{5}$ and the majority of prisoners will eventually be released into the community, ${ }^{2}$ prisons provide an opportunity to address those health needs, reduce inequalities and improve the population health overall. Meeting these goals will also reinforce the existing international policies and legal obligations outlined for prison health, detailed in table 2 and cross-referenced in our analysis of direct links of prison health to SDGs in table 1.

\section{INDIRECT LINKS OF PRISON HEALTH TO SDGS}

Our assessment identifies six goals that indirectly link prison health to SDGs. To achieve gender equality and empower women and girls (goal 5), appropriate genderspecific health services for women in prison and viable alternatives to imprisonment for this population cohort can help reduce or put an end to discrimination against this gender (Target 5.1). Similarly, the development of trauma-informed services can help reduce the impact of violence on women, as well as increase their resilience (Target 5.2). In addition, goal 7 of ensuring access to affordable, reliable, sustainable and modern energy for all can be promoted by the appropriate use of clean and sustainable energy as part of prison infrastructure management. By building a resilient infrastructure and fostering innovation (goal 9), prison research networks such as the Worldwide Prison Health Research \& Engagement Network can play a critical role in scrutinising the development and dissemination of prison health research thus enhancing scientific progress in the achievement of this goal by 2030 (Target 9.5).

The aims of goal 12 to ensure sustainable consumption and production, reduction of food waste through production and the supply chain (Targets $12 \cdot 1$ and 12.3), promotion of recycling and reuse (Target 12.5), achievement of sustainable production procurement and delivery of goods and services (Targets 12.6 and 12.7), and the improvement of education programmes regarding sustainable development, should be addressed with the prison population and environment in mind. Urgent action to combat climate change and its impacts via goal 13 should also include prisons as part of national and local disaster risk reduction and recovery plans, and the awareness of prison staff and inmates can be raised, as can their resilience or adaptive capacity to climaterelated hazards and natural disasters (Targets 13.1 and 13.3). The COVID-19 pandemic has demonstrated the need to consider prisons in resilience planning. ${ }^{14}$ In realising goal 17 of revitalising the global partnership for sustainable development, the WHO Health in Prisons Programme and its associated initiatives can develop and enhance surveillance and data systems for prison health, particularly in low/middle-income countries, in order to meet Targets $17 \cdot 9,17 \cdot 16$, and $17 \cdot 18$. Doing so will improve cooperation and provide in-roads towards the establishment of a global prison health programme.

\section{ADDRESSING THE CHALLENGES TO REALISING THE SDGS THROUGH THE PRISON HEALTH AGENDA}

Opportunities for prison health to contribute towards SDGs come with unique challenges that are politically 

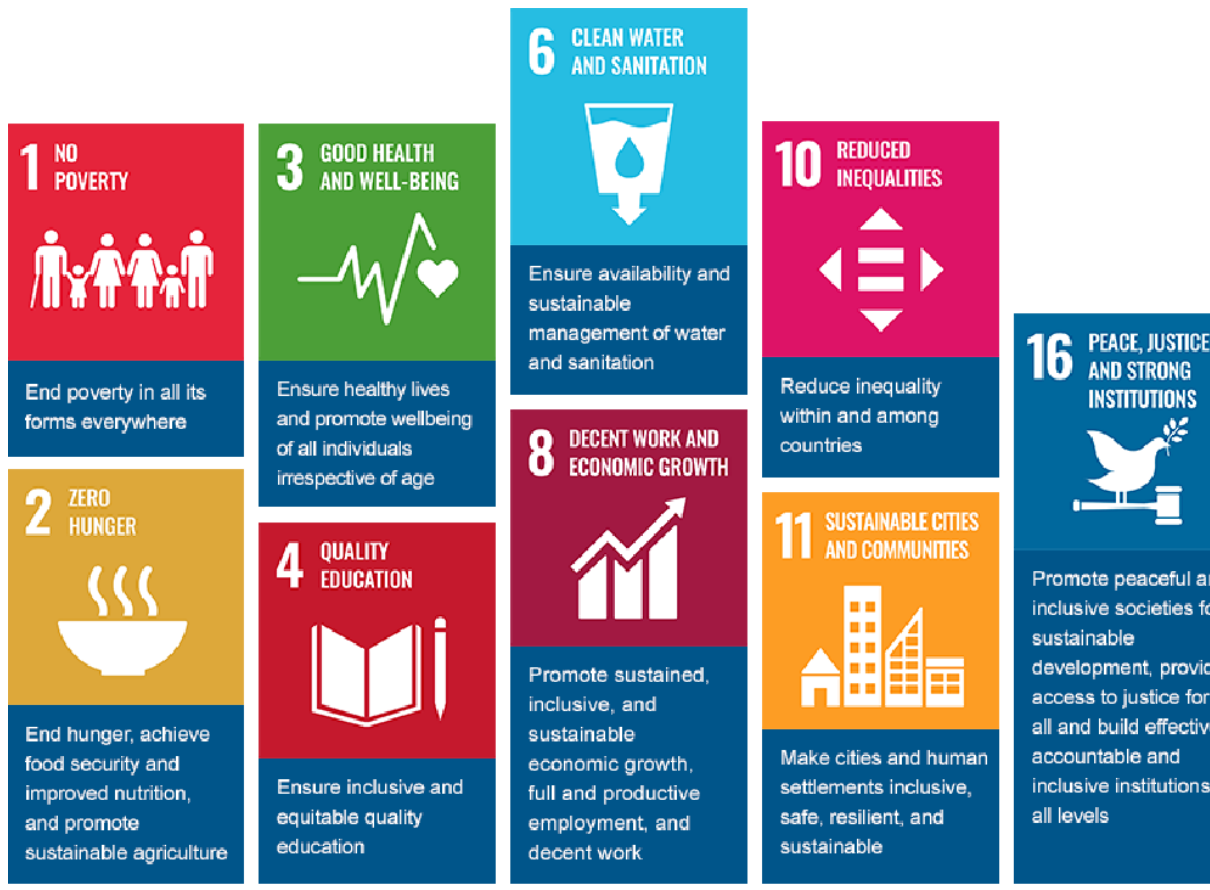

Goals directly related to prison health
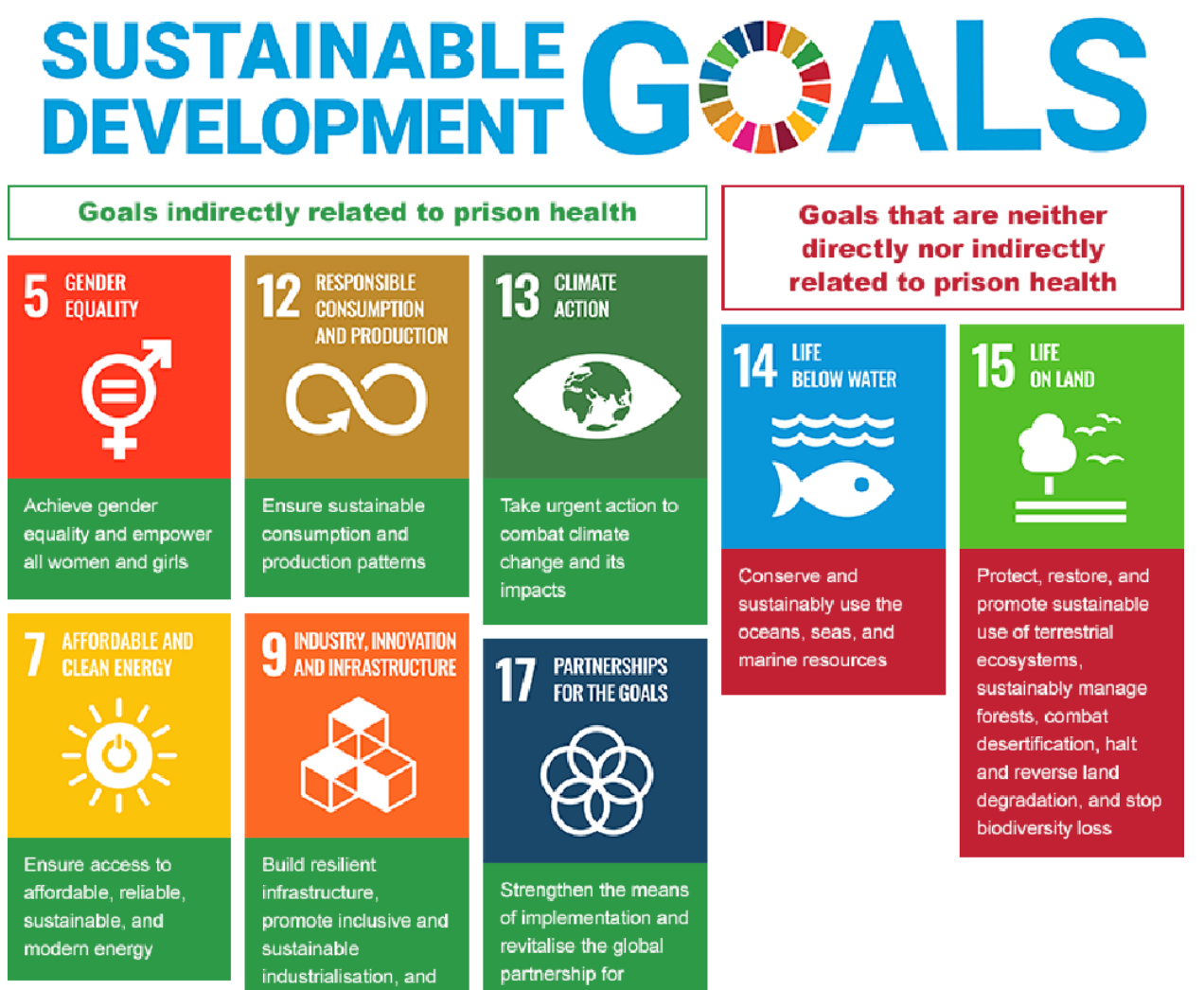

Promote peaceful and

inclusive societies for

sustainable

development, provide

access to justice for

all and build effective,

accountable and

inclusive institutions at

all levels

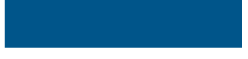




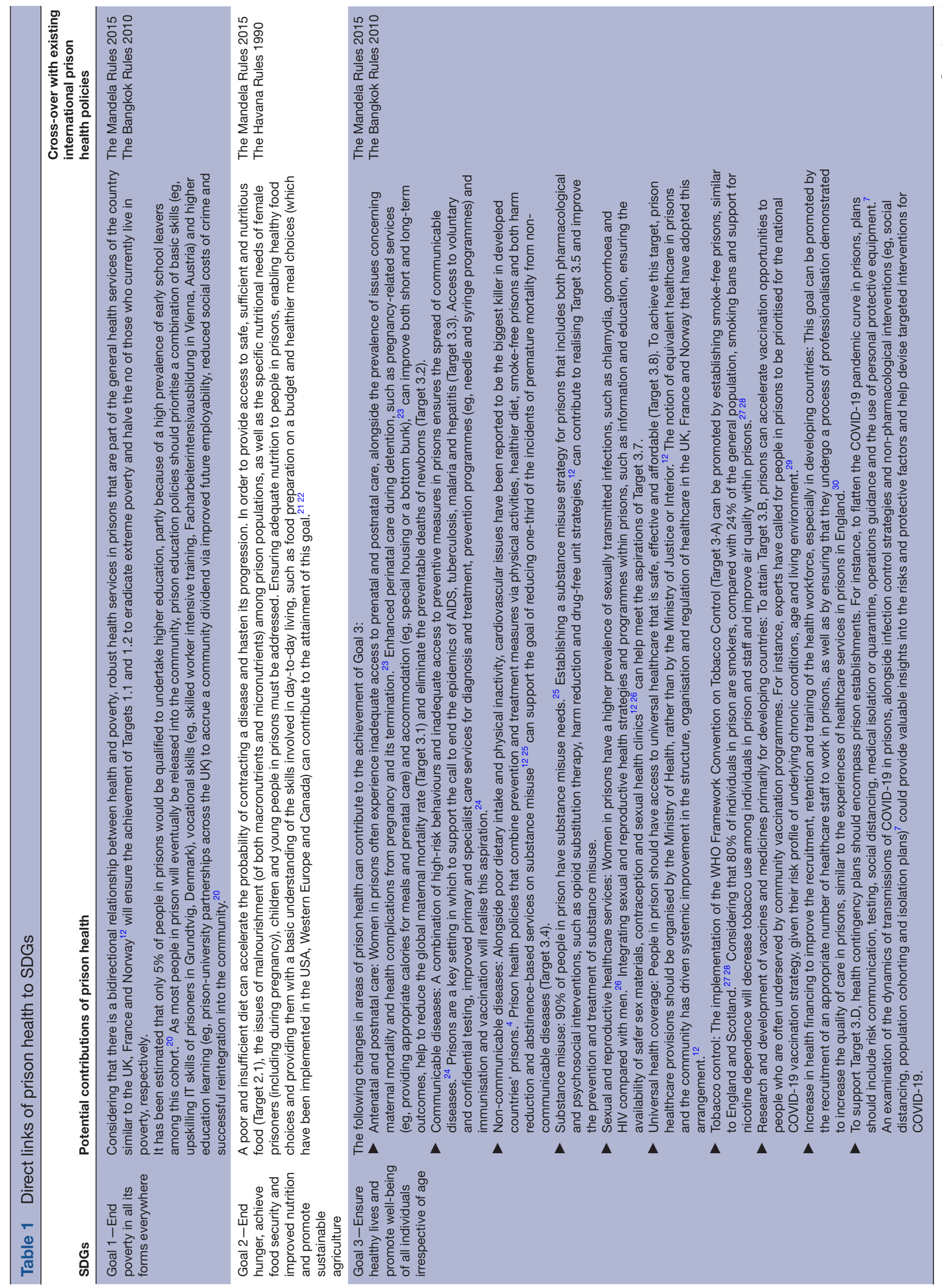




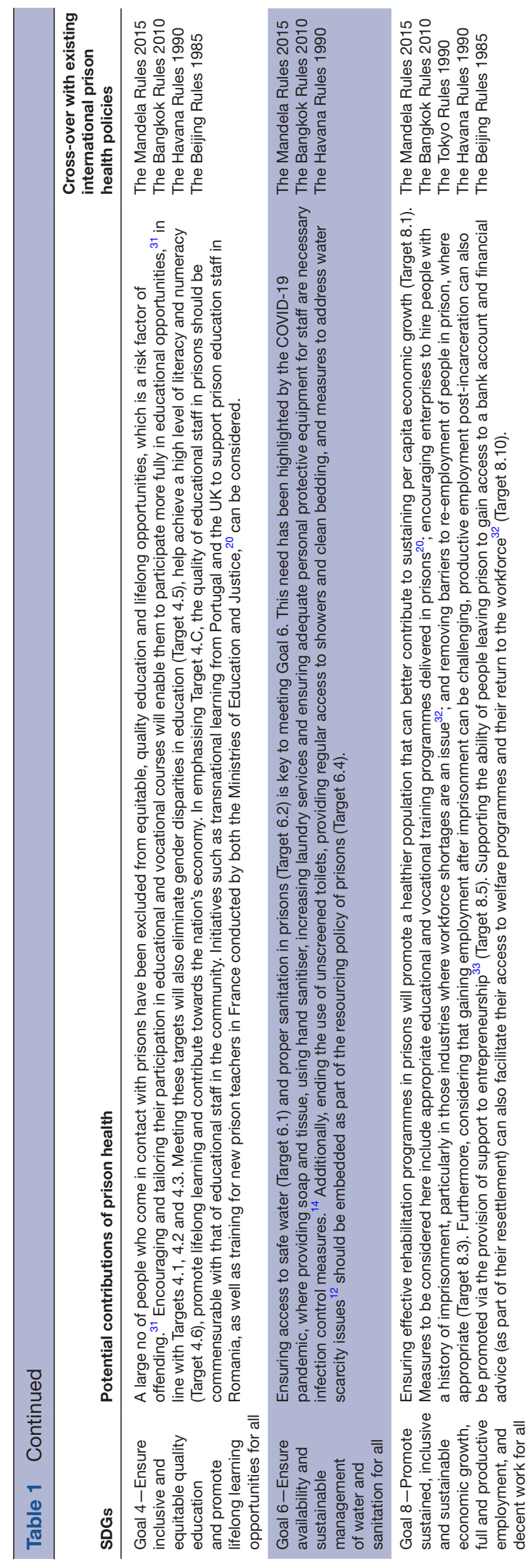

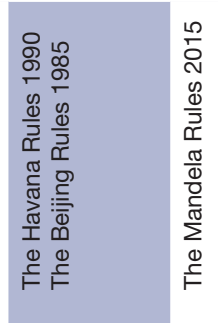

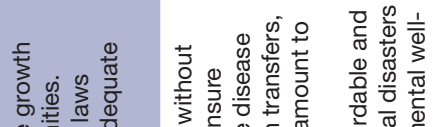

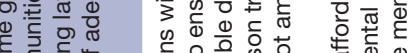

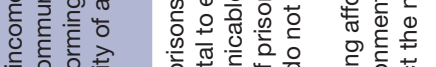

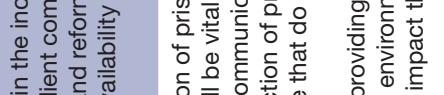

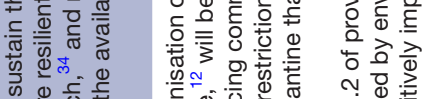

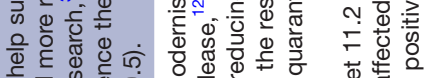

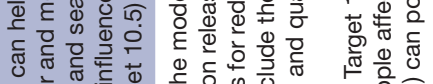

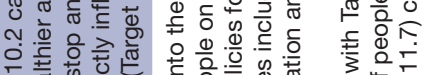

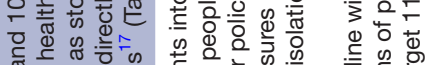

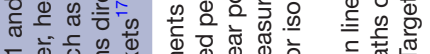
长㐫

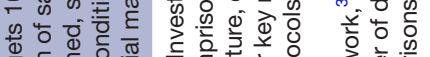

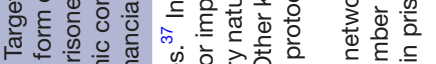

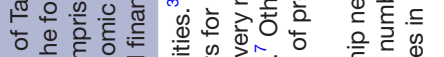

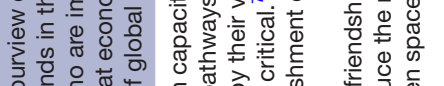

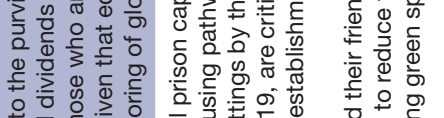

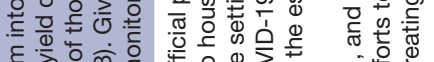
ह

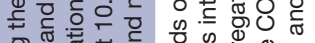

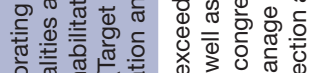

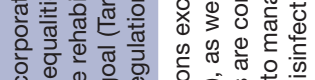

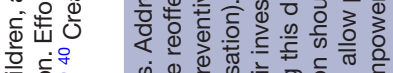

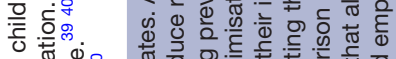

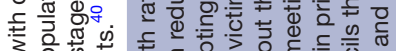

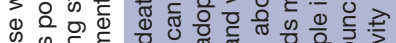

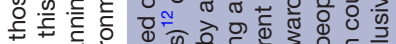

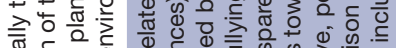
西

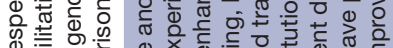

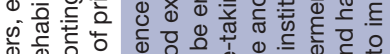

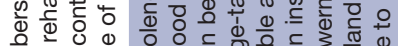

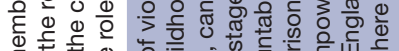
E

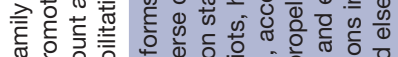
$\begin{array}{llll} & \\ 0\end{array}$ $\begin{array}{llll} & \\ 0\end{array}$

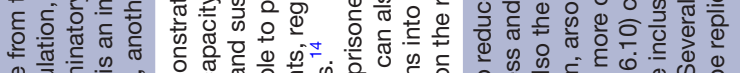

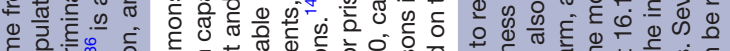

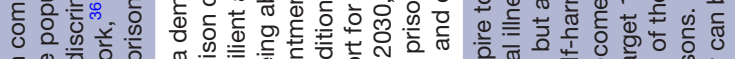

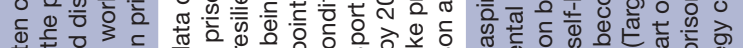

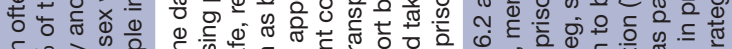

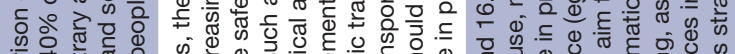

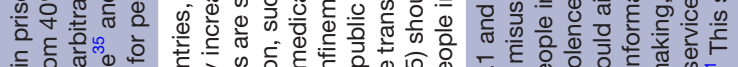
ᄃ

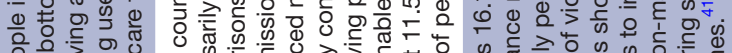

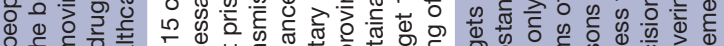

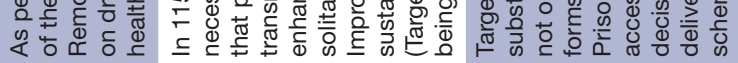

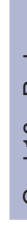

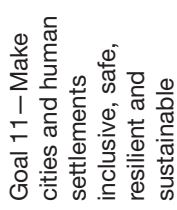

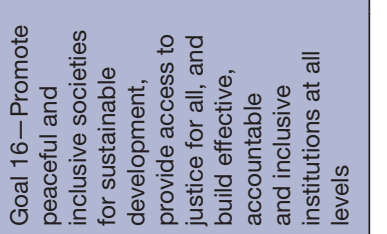

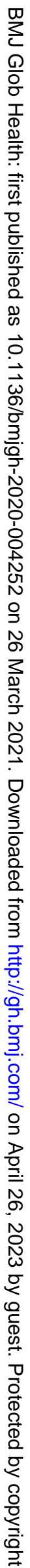


Table 2 Existing international prison health concordats

\section{Existing international prison health concordats Background information}

United Nations Standard Minimum Rules for the Treatment of Prisoners 2015 ('the Mandela Rules')
These rules were first approved in 1957, and in 2015, they were revised and adopted as the Nelson Mandela Rules to honour the legacy of the late President of South Africa, who spent 27 years in prison in the course of his struggle, referred to above. ${ }^{42}$ These rules promote humane conditions of imprisonment, raise awareness about prisoners being a continuous part of society and value the work of prison staff as a social service of particular importance. ${ }^{42}$

United Nations Rules for the Treatment of Women Prisoners and Non-custodial Measures for Women Offenders 2010 ('the Bangkok Rules')

United Nations Standard Minimum Rules for Noncustodial Measures 1990 ('the Tokyo Rules')

United Nations Standard Minimum Rules for the Administration of Juvenile Justice 1985 ('the Beijing Rules')

United Nations Rules for the Protection of Juveniles Deprived of their Liberty 1990 ('the Havana Rules')
These rules were adopted by the UN General Assembly on 21 December 2010 to address the lack of focus on the needs of women in prisons, particularly with respect to healthcare, education and employment, and family contact. ${ }^{43}$

Since 1990, these rules have urged the United Nations Member States to develop non-custodial measures within the legal system to reduce the rate of imprisonment. They range from using pretrial detention as a last resort to developing alternative sanction measures within the community by considering competing interests, such as human rights, social justice and rehabilitation. ${ }^{44}$

These 1985 rules seek to promote the health, well-being, and welfare of young people in prisons and assist them to lead a meaningful, crime-free life that fosters personal growth in the community. ${ }^{45}$

These 1990 rules urge that the imprisonment of young people should be a last resort. To foster reintegration into society, juvenile institutions should attend to these young individuals' health and welfare needs during detainment, with consideration for early release. ${ }^{46}$ economic, social and political impacts. The response in prisons has provided a valuable moment of reflection on prison health issues.

Macroeconomic conditions are commensurable with a government's commitment to providing sufficient financial resources for prison health. The price tag for delivering the SDGs is roughly between US $\$ 3.3$ and US $\$ 4.5$ trillion a year. ${ }^{15}$ The World Bank has predicted the worst recession for the global economy since World War II due to COVID-19, ${ }^{16}$ and in several European countries, fiscal austerity has persisted over the medium term. The resulting reduction in prison staff has been linked to an increase in violence, self-harm and suicide in prisons. ${ }^{17}$ As politicians are faced with competing fiscal demands, it is important to address the under-resourcing of health and welfare services in the criminal justice system and give proper consideration to prison health so that it can contribute to the SDGs.

A further challenge is posed by growing populism within countries, which might hinder progress in prison health that can contribute towards the SDGs. The trend towards tough stances on crime encourages a punitive approach to people in prisons, compromising the prison health agenda's delivery. ${ }^{17}$ Given that widespread imprisonment is economically unsustainable and can in itself pose a public health risk both in prison and in local communities, as demonstrated by COVID-19, governments should consider alternatives for those who do not need to be confined for security and public protection purposes. ${ }^{17}$ While the regressive nature of the global pandemic exposes and adds to the current system's vulnerability, countries across the globe, from the USA to Uganda and from Iran to Australia, have resorted to safe decarceration measures that go beyond secondary precautions, demonstrating how the pandemic presents us with an opportunity to accelerate the criminal justice reform that is already ongoing and critical to the attainment of SDGs. ${ }^{14}$ Progressive legislative changes and sentencing practices in a country can encourage alternatives to incarceration, emphasise that the deprivation of the liberty of individuals should only be the last resort, and reinforce the rehabilitation role in reducing the reoffending rate and contributing towards a safer and healthier society. ${ }^{12}$

In many countries, people in prisons have been sidelined within government responses to COVID-19 despite the fact that the potential for extensive outbreaks because of the higher prevalence of pre-existing poor health in imprisoned people and adverse environmental factors such as overcrowding and poor cleanliness and infection control, as well as the movement of staff and people in prison seeding and feeding outbreaks. In line with the WHO's Moscow Declaration, prison health is public health. In countries where the risk of COVID-19 has been addressed in prisons, this has been successful in decreasing the infection risk to those imprisoned and to the wider community. ${ }^{18}$ An effective national public health response to COVID-19 includes prisons.

Continuity of care beyond prison is also critical to ensuring that the investment in health gains made in 
prison are continued in the community. Through the principle of equivalence in healthcare, ${ }^{4}$ prisoners should be entitled to receive access to healthcare of the same quality as anyone in the community. Since most people in prison spend the majority of their lives in the community, there is an opportunity to realise a community dividend by providing improved healthcare in prisons. ${ }^{4}$ Doing so can impact health service utilisation within the community on release, as well as reduce health inequalities. Prison and community health programmes should embrace close cooperation and operate cohesively to ensure that no one falls through the gap as people move from one setting to another.

Prison health is part of the wider domestic public health system, and its delivery requires a concerted effort across institutions if it is to make a significant contribution to the achievement of the SDGs. Additionally, involving the prison workforce and inmates themselves in delivering the SDGs at a microlevel of governance has the potential to ensure that action is carried out effectively at a local level and that it informs the national strategy. Including these groups in coproducing and codelivering the SDGs is a way to address the criticism regarding the undemocratic nature of the MDGs. ${ }^{19}$

Such a potentially large-scale operation inevitably prompts the question: 'What would success in prison health look like in 2030?' Considering the broad and far-reaching scope of the SDGs, adopting a robust monitoring scheme from the outset could be instrumental in holding the entire system accountable for producing results based on the agreed on indicators and outcomes. Future research could build on this recommendation by developing relevant indicators that could act as the cogwheels of the SDGs, as well as case studies which can be used to evaluate opportunities and celebrate successes in implementing the SDGs across different regions of the world. We are optimistic that our approach to considering the potential contribution to the SDGs of actions regarding a vulnerable population are transferable to other settings and populations, while remaining sensitive to different political and system landscapes.

\section{CONCLUSIONS}

We have set out a novel conceptualisation of how prison health can contribute to meeting the SDGs by 2030 and have analysed how the prison health agenda can contribute to the attainment of aspirations for sustainable development even in a world challenged by a pandemic. While there are political, economic and social obstacles to delivering SDG ambitions, individual member states must seize the opportunity to effectively address these challenges at a national level through the work of policymakers, practitioners and academics.

Cooperation in transforming the vision of the SDGs into reality should benefit the development of all humans, including those who are currently disadvantaged, marginalised and excluded from global society. It is imperative that prison health be considered a useful and impactful action that can help attain the SDGs, reaching the 'furthest behind first' by 'leaving no-one behind'.

\section{Author affiliations}

${ }^{1}$ Centre for Public Health \& Wellbeing, University of the West of England Bristol, Bristol, UK

${ }^{2}$ School for Policy Studies, University of Bristol, 8 Priory Road, Bristol BS8 1TZ, UK ${ }^{3}$ European Office for the Prevention and Control of Noncommunicable Diseases (NCD Office), World Health Organization, Moscow, Leontyevsky Pereulok, Russian Federation

${ }^{4}$ Health and Justice Team, Public Health England, London, UK

${ }^{5}$ School of Primary Care, Population Sciences and Medical Education, Faculty of Medicine, University of Southampton, Southampton S016 6YD, UK

${ }^{6}$ Global Public Health, Public Health England, London, UK

Twitter Nasrul Ismail @nasrulismail27, Audrey Lazaris @Audrey_Lazaris, Éamonn 0'Moore @ejomoore and Sunita Stürup-Toft @sunitasturup

Acknowledgements We thank Dr. Carina Ferreira Borges of the WHO European Office for the Prevention and Control of Noncommunicable Diseases for her insightful feedback regarding the initial draft of our manuscript.

Contributors NI and EP conceived the research idea at the 6th WHO Prison Health Conference in Helsinki, Finland, in March 2019. All authors were involved in designing the study. NI, EP and SS-T reviewed literature on the subject, conducted the initial analysis and produced the draft manuscript. EO and AL provided further guidance on the interpretation of the data. All authors discussed, revised and approved the final manuscript after revisions.

Funding NI was supported by a UK Economic and Social Research Council (ESRC) Research Studentship Award (ESRC Grant: ES/P000630/1).

Competing interests None declared.

Patient consent for publication Not required.

Provenance and peer review Not commissioned; externally peer reviewed.

Data availability statement There are no data in this work.

Open access This is an open access article distributed in accordance with the Creative Commons Attribution 4.0 Unported (CC BY 4.0) license, which permits others to copy, redistribute, remix, transform and build upon this work for any purpose, provided the original work is properly cited, a link to the licence is given, and indication of whether changes were made. See: https://creativecommons.org/ licenses/by/4.0/.

\section{ORCID iDs}

Nasrul Ismail http://orcid.org/0000-0001-8747-6383

Audrey Lazaris http://orcid.org/0000-0002-4767-8914

Éamonn 0'Moore http://orcid.org/0000-0003-4028-0070

Emma Plugge http://orcid.org/0000-0002-8359-0071

Sunita Stürup-Toft http://orcid.org/0000-0002-6698-7042

1 United Nations. Transforming our world: the 2030 agenda for sustainable development. Available: https://sustainabledevelopment. un.org/ [Accessed 21 Sep 2020].

2 Spencer A. Removing bars to good treatment. London: NHS Magazine, 2001.

3 Dolan K, Wirtz AL, Moazen B, et al. Global burden of HIV, viral hepatitis, and tuberculosis in prisoners and detainees. Lancet 2016;388:1089-102.

4 Stürup-Toft S, O'Moore EJ, Plugge EH. Looking behind the bars: emerging health issues for people in prison. Br Med Bull 2018;125:15-23.

5 Marmot M. Social determinants of health inequalities. Lancet 2005;365:1099-104.

6 Luchenski S, Maguire N, Aldridge RW, et al. What works in inclusion health: overview of effective interventions for marginalised and excluded populations. Lancet 2018;391:266-80.

7 Kinner SA, Young JT, Snow K, et al. Prisons and custodial settings are part of a comprehensive response to COVID-19. Lancet Public Health 2020;5:e188-9. 
8 Votruba N, Thornicroft G. The importance of mental health in the sustainable development goals. BJPsych Int 2015;12:2-4.

9 Proulx KR, Ruckert A, Labonté R. Canada's flagship development priority: maternal, newborn and child health $(\mathrm{MNCH})$ and the Sustainable Development Goals (SDGs). Rev Can Etudes Dev 2016;38:39-53.

10 Haslegrave M. Ensuring the inclusion of sexual and reproductive health and rights under a sustainable development goal on health in the post-2015 human rights framework for development. Reprod Health Matters 2013;21:61-73.

11 The Lancet Public Health. Will the COVID-19 pandemic threaten the SDGs? Lancet Public Health 2020;5:e460.

12 World Health Organization. Health in prisons: a who guide to the essentials in prison health. Available: https://www.euro.who.int/ data/assets/pdf_file/0009/99018/E90174.pdf [Accessed 11 Jan 2021].

13 World Health Organization. World Health organization constitution. Available: https://www.who.int/about/who-we-are/constitution [Accessed 21 Sep 2020].

14 World Health Organization. Preparedness, prevention and control of COVID-19 in prisons and other places of detention: interim guidance 15 March 2020. Available: https://www.euro.who.int/ data/assets/pdf_file/0019/434026/Preparedness-prevention-andcontrol-of-COVID-19-in-prisons.pdf?ua=1 [Accessed $21 \mathrm{Sep}$ 2020].

15 Tangcharoensathien V, Mills A, Palu T. Accelerating health equity: the key role of universal health coverage in the sustainable development goals. BMC Med 2015;13:101.

16 World Bank. COVID-19 to plunge global economy into worst recession since World War II. Available: https://www.worldbank. $\mathrm{org} / \mathrm{en} / \mathrm{news} /$ press-release/2020/06/08/covid-19-to-plunge-globaleconomy-into-worst-recession-since-world-war-ii [Accessed 21 Sep 2020].

17 Ismail N. Rolling back the prison estate: the pervasive impact of macroeconomic austerity on prisoner health in England. J Public Health 2020;42:625-32.

18 Public Health England. Briefing paper- interim assessment of impact of various population management strategies in prisons in response to COVID-19 pandemic in England. Available: https://assets. publishing.service.gov.uk/government/uploads/system/uploads/ attachment_data/file/882622/covid-19-population-managementstrategy-prisons.pdf [Accessed 21 Sep 2020].

19 Yamey G, Shretta R, Binka FN. The 2030 sustainable development goal for health. BMJ 2014;349:g5295.

20 Hawley J, Murphy I, Souto-Otero M. Prison education and training in Europe: current state-of-play and challenges. Brussels: European Commission, 2013.

21 Leach B, Goodwin S. Preventing malnutrition in prison. Nurs Stand 2014;28:50-6.

22 Smoyer AB. Food in correctional facilities: a scoping review. Appetite 2019;141:104312.

23 Bard E, Knight M, Plugge E. Perinatal health care services for imprisoned pregnant women and associated outcomes: a systematic review. BMC Pregnancy Childbirth 2016;16:285.

24 European Centre for Disease Prevention and Control. Systematic review on the diagnosis, treatment, care and prevention of tuberculosis in prison settings. Available: https://www.ecdc.europa. eu/sites/default/files/documents/Systematic-review-tuberculosis-inprisons-May2017.pdf [Accessed 11 Jan 2021].

25 Herbert K, Plugge E, Foster C, et al. Prevalence of risk factors for non-communicable diseases in prison populations worldwide: a systematic review. Lancet 2012;379:1975-82.

26 Caviness CM, Anderson BJ, Stein MD. Prevalence and predictors of sexually transmitted infections in hazardously-drinking incarcerated women. Women Health 2012;52:119-34.
27 Plugge EH, Foster CE, Yudkin PL, et al. Cardiovascular disease risk factors and women prisoners in the UK: the impact of imprisonment. Health Promot Int 2009;24:334-43.

28 Jayes LR, Ratschen E, Murray RL, et al. Second-Hand smoke in four English prisons: an air quality monitoring study. BMC Public Health 2015;16:119.

29 Siva N. Experts call to include prisons in COVID-19 vaccine plans. Lancet 2020;396:P1870.

30 Leaman J, Richards AA, Emslie L, et al. Improving health in prisons - from evidence to policy to implementation - experiences from the UK. Int J Prison Health 2017;13:139-67.

31 United Nations. The right to education of persons in detention Report of the Special Rapporteur on the right to education. Vernor Muñoz. Available: https://www.right-docs.org/doc/a-hrc-11-8/ [Accessed 11 Jan 2021].

32 Financial Times. Can ex-prisoners help fill the UK's labour shortage? Available: https://www.ft.com/content/5212906c-ebf4-11e9-a2403b065ef5fc55 [Accessed 24 Feb 2021].

33 Centre for Entrepreneurs. From inmates to entrepreneurs: how prison entrepreneurship can break the cycle of reoffending. Available: https://centreforentrepreneurs.org/cfe-research/frominmates-to-entrepreneurs/ [Accessed 24 Feb 2021].

34 Equality and Human Rights Commission. Stop and think: a critical review of the use of stop and search powers in England and Wales. Available: https://www.equalityhumanrights.com/sites/default/files/ ehrc stop and search report.pdf [Accessed 24 Feb 2021].

35 United Nations Office on Drugs and Crime. Approaches to decriminalizing drug use \& possession. Available: https:// www.unodc.org/documents/ungass2016/Contributions/ Civil/DrugPolicyAlliance/DPA_Fact_Sheet_Approaches_to_ Decriminalization Feb2015.pdf [Accessed 24 Feb 2021].

36 Skilbrei M, Holmström C. Prostitution policy in the Nordic region: ambiguous Sympathies. Abingdon: Routledge, 2013.

37 Institute for Criminal Policy Research. Highest to Lowest Occupancy level (based on official capacity). Available: http://www. prisonstudies.org/highest-to-lowest/occupancy-level?field_region_ taxonomy_tid=All [Accessed 11 Jan 2021].

38 Plugge E, Douglas N, Fitzpatrick R. The health of women in prison study findings. Oxford: University of Oxford, 2006.

39 Gaillard JC, Prisons NF. Prisoners and disaster. Int J Disaster Risk Reduct 2012;1:33-43.

40 Baybutt M, Dooris M, Farrier A. Growing health in UK prison settings. Health Promot Int 2019;34:792-802.

41 Woodall J, Dixey R, South J. Control and choice in English prisons: developing health-promoting prisons. Health Promot Int 2014;29:474-82.

42 United Nations. The United nations standard minimum rules for the treatment of prisoners (the Nelson Mandela rules). Available: https:// undocs.org/A/RES/70/175 [Accessed 11 Jan 2021].

43 United Nations Office on Drugs and Crime. The Bangkok rules: United nations rules for the treatment of women prisoners and noncustodial measures for women offenders with their commentary. Available: https://www.unodc.org/documents/justice-and-prisonreform/Bangkok_Rules_ENG_22032015.pdf [Accessed 11 Jan 2021].

44 United Nations. United nations standard minimum rules for Noncustodial measures (the Tokyo rules). Available: https://www.ohchr. org/Documents/Professionallnterest/tokyorules.pdf [Accessed 11 Jan 2021].

45 United Nations. United nations standard minimum rules for the administration of juvenile justice (the Beijing rules). Available: https:// www.ohchr.org/Documents/Professionallnterest/beijingrules.pdf [Accessed 11 Jan 2021].

46 United Nations. United nations rules for the protection of juveniles deprived of their liberty (the havana rules). Available: https://www. ohchr.org/EN/Professionallnterest/Pages/JuvenilesDeprivedOfL iberty.aspx [Accessed 11 Jan 2021]. 